\title{
О ЗАДАЧЕ ФОРМИРОВАНИЯ ВИРТУААЬНОГО МУЗЕЙНОГО ПРОСТРАНСТВА
}

\author{
C.A. Кириллов, skirillov@jscc.ru; И.Н. Соболевская, к.ф.-м.н., nikfirst@jscc.ru \\ (Межведомственный суперкомпьютерный иентр Российской академии наук - филиал \\ ФГУ «Федеральный научный иентр Научно-исследовательский институт системных \\ исследований Российской академии наук", Аенинский просп., 32а, г. Москва, 119334, Россия)
}

В статье предложен обзор мультимедийных технологий ряда естественно-научных музеев мира. Также рассмотрена проблема формирования и предоставления пользователю высококачественного цифрового музейного контента по отдельным направлениям науки и культуры для расширения естественнонаучного и культурно-просветительского пространства знаний. Кроме того, описана электронная библиотека «Научное наследие России», которая может быть использована как средство для решения задачи интеграции междисциплинарных материалов и коллекций в единый ресурс.

Ключевые слова: мультимедийные технологии, электронная библиотека, база данных, ичифровой контент, интеграция информации, «Научное наследие России», виртуальная выставка, ичифровая коллекция, Мичурин.

Музеи - это не только культурно-образовательные и просветительские центры, но и исследовательские организации, то есть научно-исследовательская работа является одним из ведущих направлений деятельности любого из них. Научные музейные коллекции объединяют в себе теоретические знания и их наглядное подтверждение, а также составляют базовую основу для фундаментальных и прикладных исследований целого ряда областей науки. Зачастую, помимо традиционных экскурсий, посетителям музея необходимо быстро и легко получить текстовую, иллюстративную, звуковую и иную информацию о заинтересовавших их объектах экспозиции, поэтому сегодня внедрение мультимедийных и интерактивных технологий в музейное пространство становится все более популярным [1].

Мультимедийные технологии открывают новые возможности в решении задач популяризации научного и культурного музейного наследия, обеспечивают сохранность редких и ценных предметов за счет демонстрации их высококачественных цифровых копий. В частности, такие технологии призваны наглядно продемонстрировать те предметы, обозрение которых не всегда возможно. Часть музейных предметов, хранящихся в запасниках, не может быть представлена посетителю «вживую» и становится доступной с помощью технологии видеомэппинга (видеомэппинг - это технология проецирования, в которой в качестве экрана может выступать любая поверхность или объемный предмет, в проецируемом изображении учитываются все характеристики оригинального предмета: его форма, цвет, расположение в пространстве), а также посредством создания голографических витрин или других видов инсталляций.

На сегодняшний день мультимедийные технологии позволяют формировать и предоставлять пользователю высококачественный цифровой музейный контент по различным направлениям науки и культуры. Для расширения естественно-научного и культурно-просветительского пространства необходима интеграция междисциплинарных материалов и коллекций в единый ресурс. Такая задача решается, например, средствами электронной библиотеки «Научное наследие России» (ЭБ ННР) [2].

Одним из направлений интеграции музейной информации является формирование научных виртуальных выставок на основе печатных изданий, архивных материалов и музейных объектов. В процессе создания таких электронных коллекций возникает необходимость предоставления цифровых 3D-моделей естественно-научных музейных предметов, а также других мультимедийных объектов [3]. В связи с этим возникает вопрос о том, какие мультимедийные проекты созданы в музеях мира для предоставления посетителю музея или научному работнику более развернутой (или более доступной) информации.

Далее сделан обзор некоторых музеев мира, использующих современные мультимедийные технологии для формирования более подробного и яркого представления о своих фондах.

- Музей циивлизации в Оттаве (http://www.historymuseum.ca/) с помощью мультимедийных технологий предлагает посетителям проследить развитие Канады, начиная с коренных жителей и заканчивая современностью.

- Национальная портретная галерея Вашингтона (http://npg.si.edu/) предлагает посетителям при помощи 3D-технологий «потрогать» некоторые музейные экспонаты. Например, каждый может «прикоснуться» к скелету мамонта, посмертной маске Авраама Линкольна или к самолету братьев Райт.

- Музей искусств Кливленда (США) (http://www.clevelandart.org/) представляет огромный сенсорный экран, позволяющий ознакомиться с собранием музея (более 3500 экспонатов) и сформировать собственную виртуальную коллекцию нескольким людям одновременно (https://vimeo.com/64587687). 
- Музей Квинсленда (Австралия) (http://www.qm.qld.gov.au/) выпустил мобильное приложение, содержащее описание 550 видов австралийской фауны. Кроме красочных фотографий и описания животных, приложение снабжено информацией об ареале обитания или угрозе вымирания отдельных видов.

- Национальный музей Австралии (http://www.nma.gov.au/) приглашает на интерактивные экскурсии, которые проводят роботы-шахматисты - Каспаров и Честер. Во время проведения таких экскурсий в музее ведется видеотрансляция, доступная через Интернет из любой точки земного шара.

- Музей города Стелленбос (ЮАР) (http://www.stelmus.co.za/) предлагает посетителям путешествие во времени. Поворот рукоятки «машины времени» позволяет оказаться в будущем или в прошлом. На большом экране появляется изображение выбранной посетителем эпохи с рассказом на африкаанс, кхоса или английском языках.

- Японский музей «Вместилище будущего» (http://www.miraikan.jst.go.jp/), в частности, предоставляет посетителю возможность почувствовать себя космонавтом, пролетающим по околоземной орбите (https://youtu.be/lrpfU4Lduvw).

- Палеонтологический музей (Музей динозавров) префектуры Фукуи (Япония) (http://www.dinosaur.pref.fukui.jp/) представляет робота-тиранозавра, встречающего посетителей, а также мультимедийную диораму и панорамные фильмы, позволяющие ощутить себя в окружении гигантских доисторических животных (https://youtu.be/AaFFBdAQJrQ).

- Шанхайский музей науки и техники (http://www.sstm.org.cn/kjg_Web/html/kjg_english2014/ portal/index/index.htm) предлагает посетителям познакомиться с роботом-пианистом, а также с экспонатами, представляющими животных, которые визуально практически неотличимы от настоящих. Они двигаются и издают звуки, как настоящие животные (https://youtu.be/1Ytuo30c3rQ).

- Национальный музей науки, технологии и космоса МАДАТЕК (Израиль) (https://madatech.org.il/en) переносит посетителя к моментам великих открытий - от изобретения колеса до возникновения Интернета.

- Национальный морской музей Гринвича (Великобритания) (http://www.rmg.co.uk/) представляет 20-метровую волну-инсталляцию в виде 26 соединенных граней треугольника, на которые проецируются ключевые слова, фото и видео, связанные с морскими открытиями и путешествиями.

- Шведский Музей Средиземноморья в Стокгольме (http://www.varldskulturmuseerna.se/ medelhavsmuseet/) с помощью 3D-технологий «оживил» египетские мумии, которые были подвергнуты томографическому сканированию и отображены на специальном интерактивном столе. Подробная цифровая модель позволяет посетителям послойно изучать содержимое саркофага и анатомию мумии.

- Датский национальный морской музей в Хельсингере (http://mfs.dk/en/) предлагает посетителям погрузиться в глубины морей. 11 проекторов создают огромную панорамную проекцию, благодаря которой создается ощущение нахождения в открытом океане.

- Музей естественных наук MUSE в Тренто (Италия) (http://www.muse.it/en/Pages/default.aspx) представляет так называемый мультимедиатоннель с видеопроекциями и объемным звуком. У посетителя, нахождящегося в этом «тоннеле», создается иллюзия полета над Альпами и спуска по снежной трассе. Этот же музей представляет интерактивный глобус - вид Земли из космоса. Специальная программа в режиме онлайн воспроизводит движение атмосферных масс, океанов и континентов, изменение климата и т.п.

- Музей человеческого тела в Нидерландах (https://corpusexperience.nl/) представляет собой огромную фигуру сидящего человека, часть которой спрятана в здании из стекла и бетона. С помощью мультимедийных технологий за час здесь можно пройти наглядный курс анатомии, который освещает практически все процессы, происходящие в организме человека: от роста волос до работы мозга (https://youtu.be/YPi0j2yUCRQ).

- Город искусств и наук в Валенсии (http://www.cac.es/es/home.html) предлагает посетить «театр электричества», ощутить невесомость, погулять по «лесу хромосом» - среди объектов, представляющих увеличенный в миллиарды раз геном человека.

- Научный иентр «Немо» в Амстердаме (https://www.nemosciencemuseum.nl/nl/) предлагает провести опыты с химическими реактивами, оказаться внутри огромного мыльного пузыря благодаря специальным приспособлениям, «увидеть» невидимое излучение (https://youtu.be/cmG4i8uQ3Zs).

- Исторический музей Кракова (Польша) (http://www.mhk.pl/) представляет на сенсорном экране более 500 анимированных 3D-копий, найденных при раскопках предметов средневекового города.

- Государственный Дарвиновский музей в Москве (http://www.darwinmuseum.ru/) с помощью новейших технологий предлагает посетителю услышать, потрогать и уловить запах окружающего мира. Увидеть мир с высоты птичьего полета или глазами маленькой мышки, помериться силой со слоном, услышать сердцебиение колибри. С помощью мультимедийных технологий посетители могут вернуться на 3,5 миллиарда лет назад, пройти этапы эволюции и проследить за возникновением и развитием различных видов на Земле (https://youtu.be/YNljWHADGcQ). 
- Музей истории г. Екатеринбурга (http://m-i-e.ru/) представляет интерактивную мультимедийную книгу с «оживающими» страницами (https://youtu.be/2U63qAp_9v4).

- Музей природы и человека в Ханть-Мансийске (http://www.ugramuseum.ru/) предлагает интерактивную инсталляцию «Песочница», которая при помощи песка и проекционных технологий позволяет наглядно показать формирование гор и водоемов на Земле. Интерактивная «песочница» iSandBOX представляет собой оборудование, придуманное и разработанное в г. Томске. Работа такой «песочницы» построена на технологиях дополненной реальности (https://youtu.be/Dt_dgdaq9ig).

- Музейный комплекс «Вселенная воды» в Санкт-Петербурге (http://www.vodokanal-museum.ru/) погружает посетителя в водный мир при помощи видеопроекций и звукового сопровождения, передающего шум воды (https://ok.ru/video/27515292342).

Следует отметить, что, как правило, многие музеи предлагают информацию о своих фондах и доступ к отдельным цифровым копиям экспонатов. Однако остается открытым вопрос об интеграции цифровых фондов различных музеев в единый тематический информационный ресурс.

ЭБ ННР как технологическая позволяет решать задачи по формированию и поддержке междисциплинарных виртуальных выставок как средство интеграции различных ресурсов. При этом ЭБ ННР реализует удаленный открытый доступ к своим фондам для широкого круга пользователей в отличие от многих мультимедийных музейных проектов [4].

Примером внедрения данного подхода является реализация на платформе ЭБ ННР виртуальной выставки, посвященной 160-летию И.В. Мичурина «Сад жизни» (http://vim.benran.ru/). Проект создан Межведомственным суперкомпьютерным центром РАН, Российским государственным биологическим музеем им. К.А. Тимирязева и Российским государственным архивом кинофотодокументов. Виртуальная выставка позволяет посетителю сайта познакомиться с историей развития биологии и генетики в первой половине XX века, знакомит с архивными фото- и видеоматериалами той эпохи, а также представляет 3D-модели музейных объектов, связанных с жизнью и деятельностью И.В. Мичурина [5].

Создание виртуальных выставок направлено на решение задач по сохранению научного наследия российских ученых, внесших значительный вклад в развитие науки, интеграции цифровых информационных фондов (библиотек, архивов, музеев) в единый информационный ресурс и обеспечения их доступности для широкого круга пользователей, в том числе представителей научно-образовательного сообщества.

Работа выполнена в Межведомственном суперкомпьютерном ичентре РАН в рамках государственнго задания.

\section{Лumepamypa}

1. Определенов В.В., Бузина Ю.В., Пахолкова А.Ю. Виртуальные технологии в музее - опыт Пушкинского // Справ. руководителя учрежд. культуры. 2017. № 9. С. 54-63.

2. Каленов Н.Е., Соболевская И.Н., Сотников А.Н. Цифровые музейные коллекции и представление объектов естественно-научного музейного хранения в электронной библиотеке «Научное наследие России» // НТИ. Сер. 1. 2016. № 10. С. 33-38.

3. Каленов Н.Е., Савин Г.И., Серебряков В.А., Сотников А.Н. Принципы построения и формирования электронной библиотеки «Научное наследие России» // Программные продукты и системы. 2012. № 4. С. $30-40$.

4. Каленов Н.Е., Соболевская И.Н., Сотников А.Н. О взаимодействии электронной библиотеки «Научное наследие России» с естественно-научными музеями // Информационные ресурсы России. 2015. № 148 . С. 2-6.

5. Кириллов С.А., Соболевская И.Н., Сотников А.Н., Шубина Ю.В. Мультимедийные материалы в электронной библиотеке «Научное наследие России» с естественно-научными музеями // Аудиовизуальные документы: 90 лет служения Отечеству: матер. Междунар. конф. 2016. С. 46-48.

6. Интерактивные медиа. URL: http://ascreenim.ru (дата обращения 12.10.2017).

7. Системный интегратор ASCREEN. URL: http://www.ascreen.ru (дата обращения 12.10.2017).

8. LiveJournal. URL: http://ru-japan.livejournal.com (дата обращения 12.10.2017).

9. Портал культурного наследия, традиций народов России. URL: http://www.culture.ru (дата обращения 12.10.2017).

10. Электронный_журнал «Облако Mail.Ru» URL: https://cloud.mail.ru/public/8TCC/L5hV1CbRp (дата обращения 12.10.2017)/ 